\title{
Molecular Identification of Pathogenic Bacteria in Eschars from Acute Febrile Patients, Senegal
}

\author{
Oleg Mediannikov, Cristina Socolovschi, Matthieu Million, Cheikh Sokhna, Hubert Bassene, Georges Diatta, \\ Florence Fenollar, and Didier Raoult* \\ Unité de Recherche sur les Maladies Infectieuses et Tropicales Emergentes Institut de Recherche pour le Développement 198, Centre National \\ de Recherche Scientifique 7278, Université de la Méditerranée, Marseille, France; Campus Commun Université Cheikh Anta \\ Diop-Institut de Recherche pour le Développement of Hann, Dakar, Senegal
}

\begin{abstract}
Fever caused by Rickettsia felis was recently shown to play an important role in infectious diseases morbidity in sub-Saharan Africa. We collected 68 cotton swabs from fever-associated eschars in four different regions of Senegal. In 5 of 68 eschar samples (7.4\%), we have identified DNA from $R$. felis. In 49 of 68 eschar samples (72.1\%), we have identified DNA from Staphylococcus aureus. In 35 of 68 eschar samples (51.5\%), we have identified DNA from Streptococcus pyogenes, and in 4 of 68 eschar samples (5.9\%), we have identified DNA from Streptococcus pneumoniae. In 34 cases, $S$. aureus was found together with $S$. pyogenes. DNA from $R$. felis was also found in swabs from the skin of the healthy Senegalese villagers (3 of 60; $5 \%$ ) but not French urbanites. The presence of $S$. aureus and $S$. pyogenes was significantly associated with the presence of eschars in febrile patients compared with the healthy skin from the control group. Finally, we confirmed that Senegal is an endemic region for $R$. felis, which is found in both eschars and healthy skin swabs.
\end{abstract}

\section{INTRODUCTION}

Africa remains the region of the world with the lowest life expectancy and the highest mortality rates, ${ }^{1}$ and in sub-Saharan Africa, infectious diseases comprise the most important cause of mortality. ${ }^{1,2}$ Although for the majority of deaths, the cause is uninvestigated, these deaths are generally attributed to infectious diseases. In sub-Saharan Africa, clinical laboratories capable of performing diagnostic studies for emerging and neglected infectious diseases are almost always located in large cities.

In 2008, our team began to investigate the causes of nonmalarial fevers in Senegal and identified a number of bacterial pathogens responsible for acute febrile syndromes. The most intriguing feature of our studies was the identification of Rickettsia felis as a causative agent of common febrile disease in rural Senegal. ${ }^{3,4}$ Among febrile patients, the overall reported incidence of illness caused by $R$. felis was approximately $2-4 \%$, and similar results have been independently reported for Kenya. ${ }^{5,6}$ Moreover, tick-borne Rickettsia species ( $R$. conorii, $R$. africae, $R$. massiliae, $R$. aeschlimannii, and $R$. sibirica mongolitimonae) were identified in vectors and patients in Senegal, where seroprevalence against spotted fever group rickettsiae in the healthy population may reach $51 \%{ }^{7,8}$

A diagnosis of acute spotted fever group rickettsiosis is typically based on a combination of clinical (fever, rash, and presence of eschar), epidemiological (arthropod bite or contact), and laboratory data. The latter includes non-specific inflammatory signs and evidence of a rickettsial origin for the disease. These data can be both serological (enzyme-linked immunosorbent assay [ELISA] and Western blot analysis) and molecular (standard and real-time polymerase chain reaction [PCR] for the blood and eschars).

Eschar biopsy has been repeatedly shown to be very useful for the detection of rickettsial DNA in patients, because this technique is more sensitive than the detection of DNA in the blood. ${ }^{9,10}$ However, because eschar biopsies are based on an invasive technique that may be painful for patients and is

* Address correspondence to Didier Raoult, Unité de Recherche sur les Maladies Infectieuses et Tropicales Emergentes IRD 198, CNRS 7278, Université de la Méditerranée, 27 Bd Jean Moulin, Marseille 13005, France. E-mail: didier.raoult@gmail.com sometimes difficult to perform for certain areas of the body, a good alternative may be the examination of swabs from skin lesions in rickettsiosis patients. Rickettsial DNA may be present in the crusts and fluids of the eschars, even after the initiation of treatment and in cases for which serum (even convalescent) remains negative against rickettsial antigens. ${ }^{11}$ The usefulness of cotton swab PCR testing for such diagnoses has been shown for Queensland tick typhus and African tick bite fever, ${ }^{11}$ scrub typhus, ${ }^{12}$ Mediterranean spotted fever, and lymphangitisassociated rickettsiosis ${ }^{13,14}$ and $R$. parkeri infection. ${ }^{15}$

Here, we present data regarding the identification of bacterial DNA in swabs obtained from eschars from acute febrile patients in Senegal.

\section{MATERIALS AND METHODS}

Sample collection. We performed the collection of samples from eschars from febrile patients between November of 2010 and October of 2012. Collection was performed based on a network of rural dispensaries that was specifically designed in 2008 to facilitate studies of the origin of acute febrile diseases in rural Senegal. ${ }^{16}$ The study sites cover several different ecosystems, ranging from dry Sahelian in the north (Niakhar and Sine-Saloum study sites) to humid sub-Guinean in the south (Casamance and Kedougou). Two seasons are typical in these regions: dry (November to May) and rainy (June to October). The National Ethics Committee of Senegal approved the project $\left(\mathrm{N}^{\circ} 0-00.87 \mathrm{MSP} / \mathrm{DS} / \mathrm{CNERS}\right.$ and $\mathrm{N}^{\circ} 001380 \mathrm{MSP} / \mathrm{DS} /$ CNERS)..$^{3,16,17}$ The criteria for inclusion in the study were (1) the presence of fever (axillary temperature $>37.5^{\circ} \mathrm{C}$ ) as the primary symptom and (2) the presence of eschar(s) on the skin of the patient. Eschars (tache noire) in our patients were identified as single or several (grouped) local skin lesions coated by a coagulated crust or slough that developed without anterior anamnestically evident trauma. In most cases, eschars were not painful. All persons that fell under selection criteria were included in the study. The cotton swab (Copan, Brescia, Italy) was applied firmly to the surface of the crust and/or wet surface of the skin lesion. In cases in which the crust was completely dry, a piece of bandage soaked in sterile physiological solution was applied on the surface before sampling. 


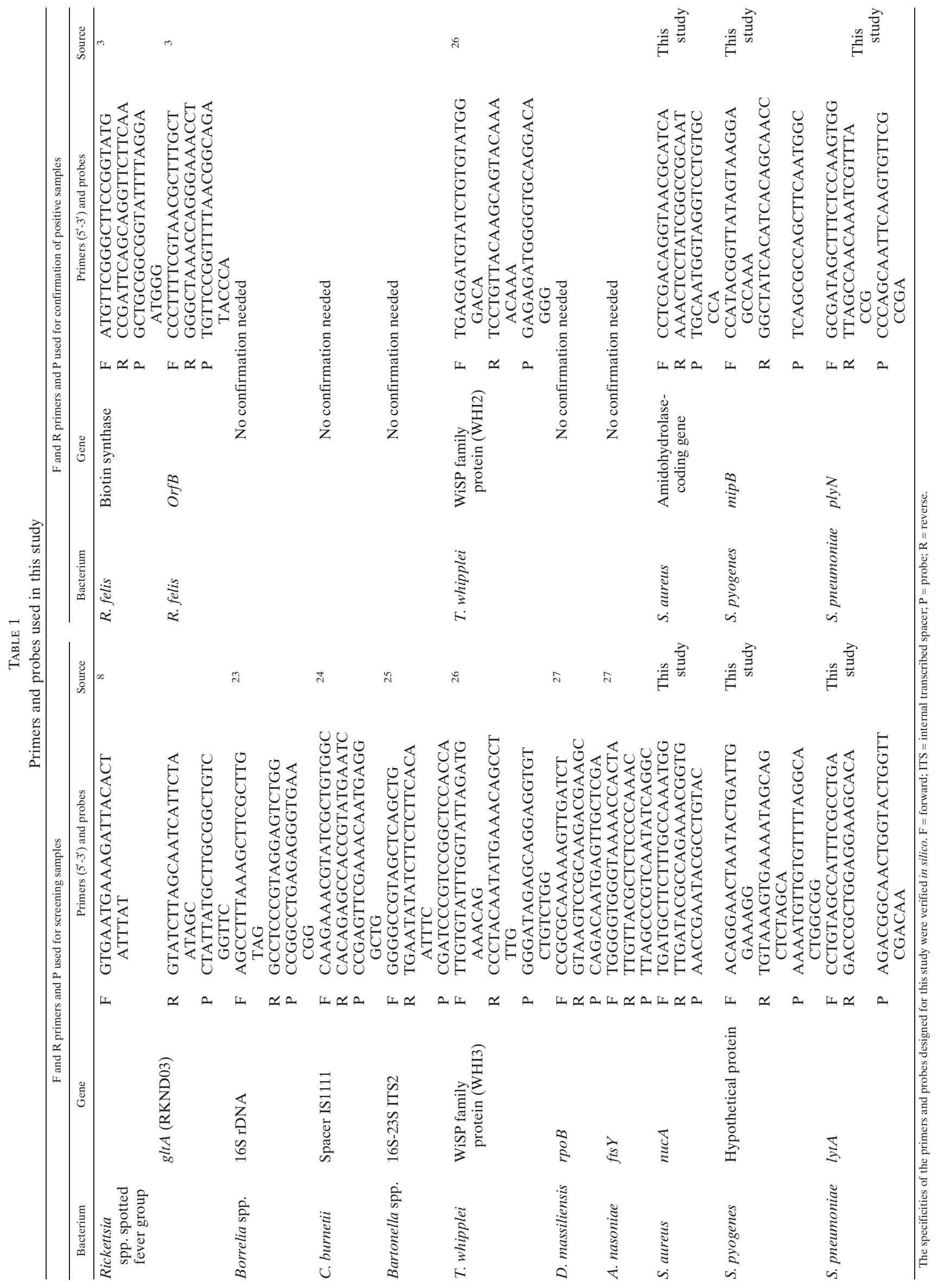


Additionally, we collected negative control samples-cotton swabs applied to healthy skin (inner surface of the forearm)from 60 inhabitants of the Sine-Saloum region (Dielmo and Ndiop villagers). Control sample collection was performed in June of 2012 (30 samples) and October of 2012 (30 samples). We also collected 58 skin swabs from 29 healthy medical students living in Marseille, France. The swabs were collected from the neck and waist from each person in December of 2012.

Molecular studies. DNA was extracted from the cotton swabs using the QIAamp DNA Mini Kit (QIAGEN, Hilden, Germany). ${ }^{13}$ The extracted DNA was stored at $4{ }^{\circ} \mathrm{C}$ until further use. Amplification and sequence detection were performed in a CFX96 Touch Thermocycler (Bio-Rad, Marnes-laCoquette, France) as follows: 15 minutes at $95^{\circ} \mathrm{C}$ followed by 40 cycles of 1 second at $95^{\circ} \mathrm{C}, 40$ seconds at $60^{\circ} \mathrm{C}$, and 40 seconds at $45^{\circ} \mathrm{C}$. The final quantitative PCR (qPCR) reaction mixture contained extracted DNA $(5 \mu \mathrm{L})$ and mix $(15 \mu \mathrm{L})$ that contained master mix $(10 \mu \mathrm{L})$ from the QuantiTect Probe PCR Kit (QIAGEN, Hilden, Germany), each primer $(0.5 \mu \mathrm{L}$, $20 \mathrm{pmol})$, probe $(0.5 \mu \mathrm{L}, 62.5 \mathrm{nmol})$, and DNase-free water $(3.5 \mu \mathrm{L})$. The qPCR was performed to screen all samples using specific primers and probes for the Rickettsia spotted fever group, R. felis, Tropheryma whipplei, Bartonella spp., Coxiella burnetii, Borrelia spp., Diplorickettsia massiliensis, Arsenophonus nasoniae, Staphylococcus aureus, Streptococcus pyogenes, and Streptococcus pneumoniae (Table 1). All positive samples were confirmed by a second round of PCR amplification targeting a different specific gene. Sterile water was used as a negative control for each test. We included the DNA of the target bacteria as positive controls. We considered samples to be positive if both specific qPCR reactions were positive using a cycle number at the threshold level for a log-based fluorescence $(\mathrm{Ct})$ value lower than 40 .

The statistical analyses were conducted using Fisher's exact test. Records with missing data (lost or improperly completed questionnaires) for a particular variable were excluded from the analysis of that variable.

\section{RESULTS}

We collected 68 swabs from 68 patients from four regions of Senegal, including 1 swab from Kédougou, 1 swab from Casamance, 32 swabs from Niakhar, and 34 swabs from SineSaloum. The mean age of the patients was 6 years old. In 5 of 68 samples $(7.4 \%)$, we identified rickettsial DNA. In all five cases, it was the DNA of $R$. felis. In 49 of 68 samples $(72.1 \%)$, we found DNA from $S$. aureus; in 35 of 68 samples $(51.5 \%)$, we found DNA from $S$. pyogenes, and in 4 of 68 samples (5.9\%), we found DNA from S. pneumoniae. In 34 cases, $S$. aureus was found together with $S$. pyogenes. No samples were positive for Borrelia spp., C. burnetii, Bartonella spp., T. whipplei, D. massiliensis, or A. nasoniae. We did not find pronounced morphological differences in the size and general appearance of the eschars from which the different bacteria were identified (Figure 1).

We additionally identified rickettsial DNA in the healthy controls but only among Senegalese villagers (Table 2), which included 3 of 60 (5\%) Rickettsia-positive individuals. In all cases, these individuals were positive for $R$. felis. No samples collected from French urbanites were positive for Rickettsia spp. $S$. aureus was identified in 1 case in France and 13 cases in Senegal. No other bacteria were identified in the French negative control group; however, in Senegal, we additionally identified $S$. pneumoniae in 3 of 60 (5\%) individuals, S. pyogenes in 3 of 60 (5\%) individuals, and T. whipplei in 1 of $60(1.7 \%)$ individuals. When the two negative control groups were compared, only the presence of $S$. aureus DNA was significantly higher $(P<0.001)$ among the Senegalese villagers.

We compared the presence of bacterial DNA identified in the eschars of febrile patients and found that the presence of DNA from $S$. aureus and $S$. pyogenes was significantly associated with the presence of these eschars compared with both negative control groups $(P<0.001)$. The presence of $R$. felis was likewise higher in patients with eschars, although no significant difference was identified between the group of the patients with eschars and the control groups. We did not find any difference (Table 2) between the presence of bacteria on skin of the waist and the neck in France, meaning that the different body parts in our study did not affect the results. The occasional presence of T. whipplei and S. pneumoniae was not associated with either eschars or healthy skin swabs.

\section{DISCUSSION}

Rickettsioses caused by rickettsiae from the spotted fever groups are often associated with the presence of eschars. ${ }^{18}$ In the case of Rocky Mountain spotted fever, eschars are reported to be very rare; however, eschars are typical in most other spotted fevers. Eschars represent skin lesions with extensive, contiguous infection by Rickettsia spp. and associated injury to local blood vessels. Rickettsial vasculitis and occlusive luminal thrombosis are associated with dermal and epidermal coagulative necrosis, resulting in the formation of these eschars. ${ }^{19}$ As such, they may represent a localized defensive reaction by the host against the penetration of the pathogenic bacterium. It is generally thought that the development of a localized defensive reaction is a good prognostic factor, and spotted fevers that generally induce multiple eschars in patients (for example, African tick bite fever) are milder than spotted fevers that are rarely accompanied by eschars (Rocky Mountain spotted fever). ${ }^{18}$

Infection by $R$. felis in Africa was described initially by two independent teams working in Senegal and Kenya. These works identified a novel healthcare problem in Africa: acute $R$. felis-induced fever that mimics malaria. ${ }^{3,6}$ Evidently, this acute fever may be responsible for a significant proportion of the non-malarial fevers in Africa. However, the epidemiology and clinical picture of this acute $R$. felis fever remain to be characterized. Indeed, the vectors and natural reservoirs of $R$. felis are not yet known in Africa. Since the first clinical descriptions of $R$. felis-associated fever, Ctenocephalides felis and $C$. canis (fleas of cats and dogs, respectively) have been implicated as the most probable vectors. In Senegal, however, $R$. felis was not identified in the vector C. felis. ${ }^{20}$ Recently, the first clinical description of a Senegalese with $R$. felisassociated fever accompanied by specific skin lesions was published. ${ }^{4}$ However, the clinical picture of $R$. felis-associated fever remains unclear.

This work was performed in a region where $R$. felis is prevalent: $R$. felis is associated with $15 \%$ of all acute fevers. ${ }^{21}$ This association is further emphasized by these data showing the presence of rickettsial DNA in both skin lesions and healthy skin swabs in Senegal and its absence in a French control group. Although $R$. felis was identified more frequently in 

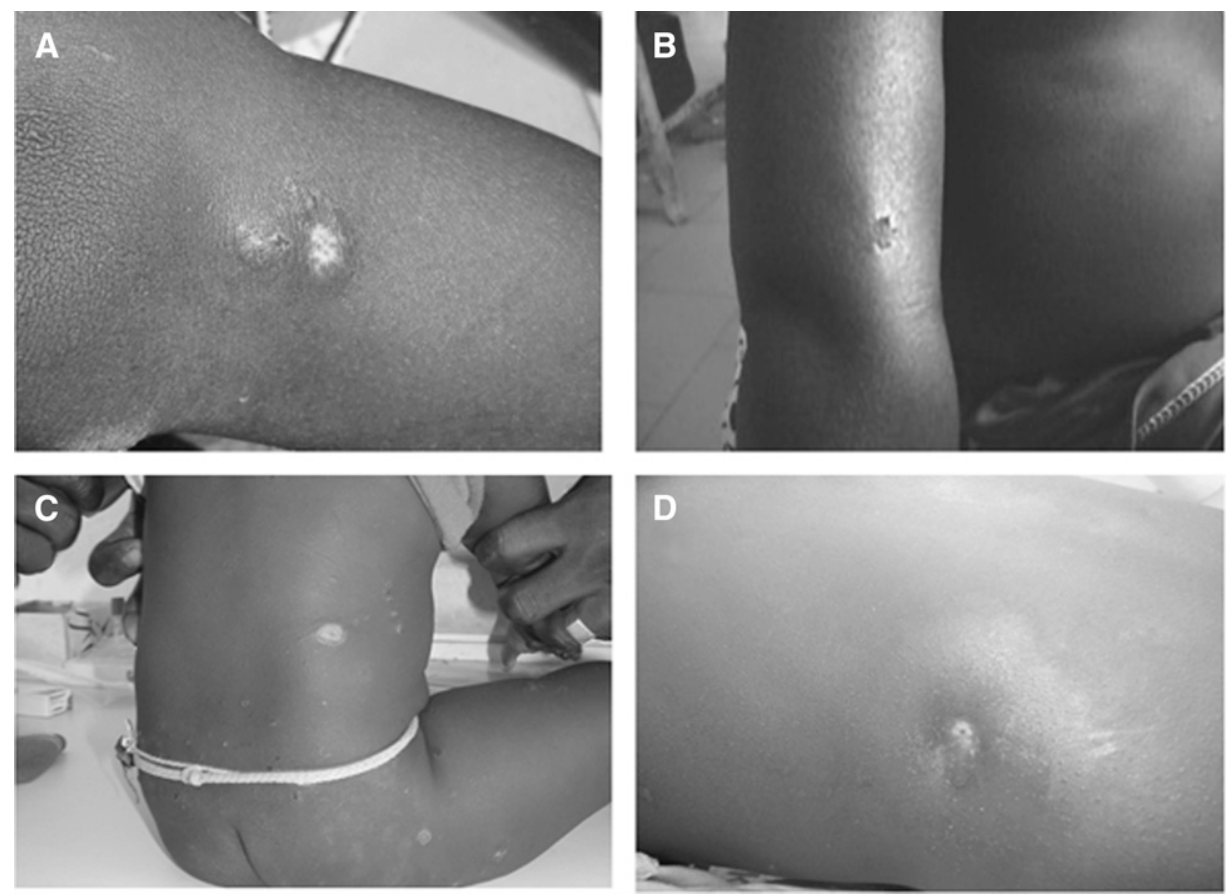

Figure 1. Eschars sampled in this study. (A) Positive for S. aureus and S. pyogenes. (B) Positive for S. pneumoniae. (C) Positive for R. felis. (D) Positive for S. pyogenes.

eschars collected from febrile patients in Senegal (7.4\% versus $5 \%$ in healthy villagers), we did not observe a statistically significant difference between the group with eschars and the control group from the same village. The possible non-technical explications of such low incidence of $R$. felis in eschars may include rare clinical presentation of $R$. felis-associated fever with typical eschars, another inoculation site of this bacterium into human body, and rapid rickettsial DNA disintegration in the eschars. Because $R$. felis DNA was not amplified from any negative PCR control (mixes or water), we suspect that $R$. felis may be common in the environment in this village. It may originate from infected arthropods, like other rickettsiae.

The presence of two common bacteria, S. aureus and $S$. pyogenes, in the eschars was unsurprising. Both bacteria are commensals of humans and frequently found in localized skin lesions (impetigo for $S$. pyogenes and furuncles for $S$. aureus). However, it is well-known that both of these bacteria may easily superinfect and colonize skin lesions that have developed from other causes. As such, the identification of one or both bacteria in our study does not necessarily mean that $S$. aureus and $S$. pyogenes caused the initial skin lesion.

We have identified T. whipplei on the skin of a healthy person in Dielmo. Humans are thought to be the predominant reservoir of $T$. whipplei in Senegal. ${ }^{22}$ Our data confirm that the bacterium is prevalent in this region. The presence of $T$. whipplei on the skin may be because of fecal contamination by $T$. whipplei.

Overall, our study showed an unexpectedly low incidence of rickettsial DNA in eschars sampled in Senegal, a region endemic for $R$. felis-associated rickettsiosis as well as other spotted fevers. $R$. felis was found in not only eschars but also, the healthy skin swabs, giving reasons for future investigations of the reservoirs of this bacterium. The presence of $S$. aureus and $S$. pyogenes was significantly associated with the presence

TABLE 2

Results of screens for the presence of pathogenic bacteria in negative controls (intact skin swabs)

\begin{tabular}{|c|c|c|c|c|c|c|}
\hline Bacterium identified & $\begin{array}{l}\text { Senegalese villagers, } \\
\text { June of } 2012(30)\end{array}$ & $\begin{array}{l}\text { Senegalese villagers, } \\
\text { October of } 2012(30)\end{array}$ & $\begin{array}{c}\text { Total in } \\
\text { Senegal (60) }\end{array}$ & $\begin{array}{l}\text { French urbanites, } \\
\text { December of 2012, neck (29) }\end{array}$ & $\begin{array}{c}\text { French urbanites, } \\
\text { December of 2012, waist (29) }\end{array}$ & $\begin{array}{c}\text { Total in } \\
\text { France (58) }\end{array}$ \\
\hline $\begin{array}{l}\text { Rickettsia spp. } \\
\quad \text { (spotted fever group) }\end{array}$ & $10 \%(3 / 30)$ & 0 & $5 \%(3 / 60)$ & 0 & 0 & 0 \\
\hline Including $R$. felis & $10 \%(3 / 30)$ & 0 & $5 \%(3 / 60)$ & 0 & 0 & 0 \\
\hline S. aureus & $36.7 \%(11 / 30)$ & $6.7 \%(2 / 30)$ & $21.7 \%(13 / 60)$ & $3.4 \%(1 / 29)$ & 0 & $1.7 \%(1 / 58)$ \\
\hline S. pneumoniae & $3.3 \%(1 / 30)$ & $6.7 \%(2 / 30)$ & $5 \%(3 / 60)$ & 0 & 0 & 0 \\
\hline S. pyogenes & $10 \%(3 / 30)$ & 0 & $5 \%(3 / 60)$ & 0 & 0 & 0 \\
\hline T. whipplei & 0 & $3.3 \%(1 / 30)$ & $1.7 \%(1 / 60)$ & 0 & 0 & 0 \\
\hline Bartonella spp. & 0 & 0 & 0 & 0 & 0 & 0 \\
\hline Borrelia spp. & 0 & 0 & 0 & 0 & 0 & 0 \\
\hline C. burnetii & 0 & 0 & 0 & 0 & 0 & 0 \\
\hline D. massiliensis & 0 & 0 & 0 & 0 & 0 & 0 \\
\hline A. nasoniae & 0 & 0 & 0 & 0 & 0 & 0 \\
\hline
\end{tabular}


of eschars in febrile patients compared with the healthy skin from the control group.

Received October 28, 2013. Accepted for publication June 6, 2014.

Published online September 8, 2014.

Acknowledgments: The authors thank all of the villagers who participated in the study and Annick Bernard, Aliou Diallo, Khadim Mbacke Leye, and Denis Pyak for technical support.

Financial support: The authors thank the Agence National de Recherche, Grant MALEMAF (Research of Emergent Pathogens in Africa), and the La Fondation Méditerranée Infection for financial support.

Authors' addresses: Oleg Mediannikov, Cristina Socolovschi, Matthieu Million, and Didier Raoult, Faculte de Medecine, Unité de Recherche sur les Maladies Infectieuses et Tropicales Emergentes, Unité Mixte de Recherche Institut de Recherche pour le Développement 198, Marseille, France, E-mails: oleg.mediannikov@ird.fr, cristina .socolovschi@univ-amu.fr, matthieumillion@gmail.com, and didier .raoult@gmail.com. Cheikh Sokhna, Hubert Bassene, and Georges Diatta, Unité de Recherche sur les Maladies Infectieuses et Tropicales Emergentes, Unité Mixte de Recherche Institut de Recherche pour le Développement 198, Dakar, Senegal, E-mails: cheikh.sokhna@ird.fr, hubert.bassene@ird.fr, and georges.diatta@ird.fr. Florence Fenollar, Faculté de Médecine, Unité des Rickettsies, Marseille, France, E-mail: florence.fenollar@univ-amu.fr.

\section{REFERENCES}

1. World Health Statistics of the WHO, 2012. WHO Technical Report Series. Geneva: WHO.

2. Adjuik M, Smith T, Clark S, Todd J, Garrib B, Kinfu Y, Kahn K, Mola M, Ashraf A, Masanja H, Adazu K, Sacarlal J, Alam N, Marra M, Gbangou A, Mwageni E, Binka F, 2006. Cause-specific mortality rates in sub-Saharan Africa and Bangladesh. Bull World Health Organ 84: 181-188.

3. Socolovschi C, Mediannikov O, Sokhna C, Tall A, Diatta G, Bassene H, Trape JF, Raoult D, 2010. Rickettsia felis, a common cause of uneruptive fever in rural Senegal. Emerg Infect Dis 16: $1140-1142$.

4. Mediannikov O, Fenollar F, Bassene H, Tall A, Sokhna C, Trape JF, Raoult D, 2012. Description of "Yaaf", the vesicular fever caused by acute Rickettsia felis infection in Senegal. J Infect 66: 536-540.

5. Maina AN, Knobel DL, Jiang J, Halliday J, Feikin DR, Cleaveland S, Ng'ang'a Z, Junghae M, Breiman RF, Richards AL, Njenga MK, 2012. Rickettsia felis infection in febrile patients, western Kenya, 2007-2010. Emerg Infect Dis 18: 328-331.

6. Richards AL, Jiang J, Omulo S, Dare R, Abdirahman K, Ali A, Sharif SK, Feikin DR, Breiman RF, Njenga MK, 2010. Human Infection with Rickettsia felis, Kenya. Emerg Infect Dis 16: 1081-1086.

7. Mediannikov O, Trape JF, Diatta G, Parola P, Fournier PE, Raoult D, 2010. Rickettsia africae, western Africa. Emerg Infect Dis 16: 571-573.

8. Mediannikov O, Diatta G, Fenollar F, Sokhna C, Trape JF, Raoult D, 2010. Tick-borne rickettsioses, neglected emerging diseases in rural Senegal. PLoS Negl Trop Dis 4: e821.

9. Mediannikov O, Sidelnikov Y, Ivanov L, Fournier PE, Tarasevich I, Raoult D, 2006. Far eastern tick-borne rickettsiosis: identification of two new cases and tick vector. Ann N Y Acad Sci 1078: 80-88.

10. Fournier PE, Raoult D, 2004. Suicide PCR on skin biopsy specimens for diagnosis of rickettsioses. J Clin Microbiol 42: $3428-3434$.
11. Wang JM, Hudson BJ, Watts MR, Karagiannis T, Fisher NJ, Anderson C, Roffey P, 2009. Diagnosis of Queensland tick typhus and African tick bite fever by PCR of lesion swabs. Emerg Infect Dis 15: 963-965.

12. Lee SH, Kim DM, Cho YS, Yoon SH, Shim SK, 2006. Usefulness of eschar PCR for diagnosis of scrub typhus. J Clin Microbiol 44: $1169-1171$.

13. Bechah Y, Socolovschi C, Raoult D, 2011. Identification of rickettsial infections by using cutaneous swab specimens and PCR. Emerg Infect Dis 17: 83-86.

14. Mouffok N, Socolovschi C, Benabdellah A, Renvoise A, Parola P, Raoult D, 2011. Diagnosis of rickettsioses from eschar swab samples, Algeria. Emerg Infect Dis 17: 1968-1969.

15. Myers T, Lalani T, Dent M, Jiang J, Daly PL, Maguire JD, Richards AL, 2013. Detecting Rickettsia parkeri infection from eschar swab specimens. Emerg Infect Dis 19: $778-780$.

16. Sokhna C, Mediannikov O, Fenollar F, Bassene H, Diatta G, Tall A, Trape JF, Drancourt M, Raoult D, 2013. Point-of-care laboratory of pathogen diagnosis in rural Senegal. PLoS Negl Trop Dis 7: e1999.

17. Trape JF, Rogier C, Konate L, Diagne N, Bouganali H, Canque B, Legros F, Badji A, Ndiaye G, Ndiaye P, 1994. The Dielmo project: a longitudinal study of natural malaria infection and the mechanisms of protective immunity in a community living in a holoendemic area of Senegal. Am J Trop Med Hyg 51: $123-137$

18. Parola P, Paddock CD, Socolovschi C, Labruna MB, Mediannikov O, Kernif T, Abdad MY, Stenos J, Bitam I, Fournier PE, Raoult D, 2013. Update on tick-borne rickettsioses around the world: a geographic approach. Clin Microbiol Rev 26: $657-702$.

19. Walker DH, Gay RM, Valdes-Dapena M, 1981. The occurrence of eschars in Rocky Mountain spotted fever. J Am Acad Dermatol 4: $571-576$.

20. Roucher C, Mediannikov O, Diatta G, Trape JF, Raoult D, 2012. A new Rickettsia species found in fleas collected from human dwellings and from domestic cats and dogs in Senegal. Vector Borne Zoonotic Dis 12: 360-365.

21. Mediannikov O, Socolovschi C, Edouard S, Fenollar F, Mouffok N, Bassene H, Diatta G, Tall A, Niangaly H, Doumbo O, Lekana-Douki JB, Znazen A, Sarih M, Ratmanov P, Richet H, Ndiath O, Sokhna C, Parola P, Raoult D, 2013. Common epidemiology of Rickettsia felis infection and malaria, Africa. Emerg Infect Dis 19: 1775-1783.

22. Keita AK, Mediannikov O, Ratmanov P, Diatta G, Bassene H, Roucher C, Tall A, Sokhna C, Trape JF, Raoult D, Fenollar F, 2013. Looking for Tropheryma whipplei source and reservoir in rural Senegal. Am J Trop Med Hyg 88: 339-343.

23. Parola P, Diatta G, Socolovschi C, Mediannikov O, Tall A, Bassene H, Trape JF, Raoult D, 2011. Tick-borne relapsing fever borreliosis, rural Senegal. Emerg Infect Dis 17: 883-885.

24. Mediannikov O, Fenollar F, Socolovschi C, Diatta G, Bassene H, Molez JF, Sokhna C, Trape JF, Raoult D, 2010. Coxiella burnetii in humans and ticks in rural Senegal. PLoS Negl Trop Dis 4: e654.

25. Angelakis E, Rolain JM, Raoult D, Brouqui P, 2011. Bartonella quintana in head louse nits. FEMS Immunol Med Microbiol 62: $244-246$

26. Fenollar F, Mediannikov O, Socolovschi C, Bassene H, Diatta G, Richet H, Tall A, Sokhna C, Trape JF, Raoult D, 2010. Tropheryma whipplei bacteremia during fever in rural West Africa. Clin Infect Dis 51: 515-521.

27. Subramanian G, Sekeyova Z, Raoult D, Mediannikov O, 2012. Multiple tick-associated bacteria in Ixodes ricinus from Slovakia. Ticks Tick Borne Dis 3: 406-410. 